\title{
TeOlogia I Moralność
}

Том 11, 2012

\section{JÓZEF MŁYŃSKI}

Uniwersytet Kardynała Stefana Wyszyńskiego w Warszawie

Uniwersytet Papieski Jana Pawła II w Krakowie

\section{Wykluczenie społeczne wyzwaniem dla współczesnego świata}

\section{Social Exclusion as a Challenge to Contemporary World}

Zjawisko marginalizacji jest powszechne, tak w przestrzeni, jak i w czasie. Przybiera wiele różnych form i pociaga za sobą wielorakie skutki. Marginalizacja powodowana jest wieloma czynnikami. Do tych ważnych należałoby zaliczyć: problemy z pracą, ubóstwo, biedę, alkoholizm, narkomanię, bezdomność, dysfunkcyjność i niepełnosprawność... Kojarzy się nam także z wygnaniem, odizolowaniem jednostki, wyłączeniem jej ze społeczeństwa i brakiem akceptacji w środowisku.

Nadto zjawisko to dotyczy braku możliwości korzystania z życia społecznego. Marginalizację tę dość często lokujemy obok wykluczenia społecznego albo w ogóle utożsamiamy z nim. Dotyczy ona osób, rodzin, grup ludności, które: żyją w niekorzystnych warunkach ekonomicznych (w ubóstwie materialnym); zostają dotknięte niekorzystnymi procesami społecznymi, wynikającymi z masowych i dynamicznych zmian rozwojowych, np. dezindustrializacji, kryzysów, gwałtownego upadku branż czy regionów; nie zostały wyposażone w kapitał życiowy umożliwiający im osiaggnięcie normalnej pozycji społecznej, odpowiedniego poziomu kwalifikacji, wejście na rynek pracy lub założenie rodziny, co dodatkowo utrudnia dostosowywanie się do zmieniających się warunków społecznych i ekonomicznych; nie posiadają dostępu do odpowiednich instytucji zapewniających wyposażenie w kapitał życiowy, jego rozwój i pomnażanie, co ma miejsce w wyniku niedorozwoju tych instytucji spowodowanego brakiem priorytetów, brakiem środków publicznych, niską efektywnością funkcjonowania; doświadczają przejawów dyskryminacji, zarówno wskutek niedorozwoju właściwego ustawodawstwa, jak i kulturowych uprzedzeń oraz stereotypów; mają cechy utrudniające im korzystanie z powszechnych zasobów społecznych ze względu 
na zaistnienie: niesprawności, uzależnienia, długotrwałej choroby albo innych cech indywidualnych; są przedmiotem niszczącego działania innych osób, np.: przemocy, szantażu, indoktrynacji.

W tym kontekście warto zastanowić się nad zjawiskiem wykluczenia społecznego. Nie jest ono młode i dotyczy dużej liczby ludności. Analizę rozpoczniemy od zdefiniowania zagadnienia wykluczenia, po czym wskażemy jego podmiot i możliwości pomocy jednostkom skazanym na nie.

\section{OD EKSKLUZJI - MARGINALIZACJI DO WYKLUCZENIA SPOŁECZNEGO}

Zdefiniowanie terminu wykluczenie społeczne należałoby rozpocząć od zdefiniowania ubóstwa - biedy. Zjawiska tego nie można traktować jako novum w socjologii. Istnieje bowiem zgoda między socjologami, że zjawiskiem poprzedzającym wykluczenie jest marginalizacja, ekskluzja społeczna. Pierwsze jej symptomy opisano w pionierskiej realizacji szkoły chicagowskiej, której przedstawicielem był R. Park. Jego zdaniem, ekskluzja to podstawowa strategia zamykająca grupie dostęp do jej zasobów i możliwości, jakimi dysponuje. Stąd przez ekskluzję w owym czasie rozumiano wyłączenie poza margines głównego nurtu życia społecznego. Zasadnicze w tej kwestii staje się pytanie dotyczące wyłączenia społecznego, a dokładniej wyłączenia z czego jest [ekskluzja]. Jak się wydaje, wykluczonym można być w szeroko rozumianej praktyce życia społecznego. Uczestniczenie w ekskluzji oznacza branie udziału w marginalizacji.

Zdaniem wielu autorów, istnieją cztery wymiary marginalizacji, a więc wyłączenie:

- z aktywności zawodowej, czyli bezrobocie,

- z konsumpcji, czyli jakiś niedostatek albo trwałe ubóstwo,

- ze społeczności - nazwijmy to - „normalnych”,

- z pewnych mechanizmów władzy, wpływów, czyli marginalizacja kulturowa.

Można by je zawrzeć w czterech określeniach; są nimi marginalizacja: zawodowa, konsumpcyjna, społeczna i kulturowa.

Wydaje się jednak, że pojęcie ekskluzji powstało raczej w pewnej opozycji do terminu bieda. Można stwierdzić, że oba te zjawiska dotyczą tego samego zagadnienia, tych samych kategorii osób. Istnieją zatem rozmaite sposoby konceptualizacji biedy. Nadto jest ona implikowana różnymi uwarunkowaniami egzystencji jednostek. Ontologiczne jej znaczenie wynika z niedostatku środków do życia, których niejednokrotnie brakuje ludziom, aby zachować status quo w zmieniającym się społeczeństwie. Jest to zjawisko, które z jednej strony de- 
prymuje człowieka, a z drugiej budzi wielkie oczekiwanie osób, u których brak zasobów wywołuje lęk przed przyszłością.

Samo pojęcie biedy funkcjonowało w świadomości społecznej najczęściej jako brak środków materialnych do życia, niedostatek. Bieda oznacza pozostawanie poniżej pewnego zmiennego w czasie progu dochodowego lub poniżej progu realizacji potrzeb w odniesieniu do jednostki, rodziny lub grupy społecz$n^{1}{ }^{1}$. Towsendem uważa, że jest to niezdolność do uczestnictwa w społeczeństwie, niezdolność do partycypacji społecznej wynikająca z braku zasobów². Przywołana definicja prezentuje biedę w ujęciu ekonomicznym, co istotnie wyklucza rozumienie tego zjawiska $\mathrm{w}$ odniesieniu do niematerialnych jej aspektów. W tym przypadku z pomocą przychodzi szeroka definicja ONZ wskazująca na jej elementy w odniesieniu do: braku udziału w podejmowaniu decyzji, bezsilności, podatności na przemoc czy wreszcie zamachu na ludzką godność 3 .

Kolejną definicję przytacza S. Ringen, twierdząc, że w semantyce omawianego zagadnienia należy uwzględnić niski poziom życia, oznaczający deprywację związaną ze sposobem życia z powodu niewystarczających zasobów, które nie pozwalają na uniknięcie biedy ${ }^{4}$. Kwestia ta implicite zawiera się w pomiarach ubóstwa prowadzącego do braku osiągania przez osoby pewnej skali dochodów lub niemożności osiagania dochodu w ogóle. Należałoby się zgodzić z A. Senem, którego badania dowodzą alternatywnego spojrzenia na rolę niskiego dochodu w operacjonalizacji definicji biedy. Możliwości oznaczają jedynie to, co dana osoba może zrobić, lub to, kim może być. Decydującym czynnikiem jest tu wolność prowadzenia życia, które ludzie cenią․ Takie rozumienie wydaje się zależne z jednej strony od możliwości jednostki, a z drugiej od jej dochodów.

W ustaleniu znaczenia pojęcia biedy ważna jest jeszcze jedna kwestia, mianowicie problem konceptualizacji. Można definiować ją jako zjawisko subiektywne i obiektywne albo relatywne ${ }^{6}$ lub absolutne ${ }^{7}$. Zaistniała dychotomia naka-

\footnotetext{
${ }^{1}$ Natura i kwestia ubóstwa, red. W. Toczyński, Gdańsk-Warszawa 1991, s. 12.

${ }^{2}$ R. Lister, Bieda, Warszawa 2007, s. 26.

${ }^{3}$ Tamże.

${ }^{4}$ S. Ringen, The Possibility of Politics, Oxford 1987, s. 146.

${ }^{5}$ A. Sen, Rozwój $i$ wolność, Poznań 2002, s. 98.

${ }^{6}$ Deprywacja [bieda] relatywna dotyczy zaś tych jednostek, które mają wystarczające środki do przeżycia, ale ich dochody są znacząco mniejsze od reszty jednostek mieszkających w tym samym społeczeństwie. Standard ich życia jest wprawdzie poniżej średniego poziomu, ale nie stanowi tylko ich minimum dochodów. Por. J. Młyński, Deprywacja społeczna a praca socjalna. Komplementarność zjawisk czy znaczna różnica, „Praca Socjalna” 4 (2008), s. 3-14.

${ }^{7}$ Deprywacja [bieda] absolutna odnosi się do możliwości uzyskania przez jednostkę zasobów potrzebnych do zaspokojenia jej egzystencji pozwalającej osiagnać jedynie minimum środków na przetrwanie. Ubóstwo w tym wymiarze dotyczy jedynie tych, którzy pozostają poniżej owego minimum. Określenie to wskazuje jedynie na przetrwanie jednostek w danym społeczeństwie. Por. J. Młyński, Deprywacja społeczna a praca socjalna, s. 7.
} 
zuje obserwatorowi wyjaśnić to zjawisko w kategoriach strukturalnych, by w ten sposób przyjąc stanowisko albo założenie dotyczące kwestii dystrybucji dóbr w społeczeństwie, które implikują niedostatek lub brak zasobów jednostki bądź rodziny. Stąd zazwyczaj bieda dzielona jest na absolutną lub relatywną. Granicą obu jest linia minimalnej ilości zasobów, minimalnego standardu pozwalającego na w miarę godziwe życie.

Nieco światła na zagadnienie natury biedy (ekskluzji społecznej) rzuca teoria potrzeb T. Kocowskiego. Zakłada on, że potrzeba to pojęcie relacyjne określające związek między przedmiotem - celem a stworzonymi warunkami, które potrzebne są do jego realizacji ${ }^{8}$. Niemniej jednak bieda jest zjawiskiem stopniowalnym, dlatego można być biednym w zależności od: pracy, problemów w rodzinie, choroby, niepełnosprawności; w rzeczy samej linia jej jest dość arbitralna. W tym znaczeniu ekskluzję społeczną należałoby określić w potrójny sposób ${ }^{9}$ :

- Po pierwsze, ekskluzję społeczną traktuje się zarówno jako pewien stan, rezultat albo konsekwencję zmian społecznych, jak i jako proces.

- Po drugie, w wielu definicjach podkreśla się, że „ekskluzja społeczna” odnosi się do nowych zjawisk społecznych: nowej biedy, nowych rozłamów i wymiarów nierówności społecznych, a nowe zjawiska wymagają nowych terminów. Ich nowość ma wiele źródeł. Czasami wynika z faktu, iż jeszcze do niedawna zjawiska te były nie do wyobrażenia $w$ bogatych społeczeństwach dobrobytu, a ponadto nie dają się one wythumaczyć tradycyjnymi teoriami klas lub stratyfikacji społecznej. Czasami znów rzecz w tym, że ujawniane są nowe czynniki strukturyzacji i stratyfikacji społecznej, czego przykładem są studia typu gender and class lub ethclass. W końcu zjawiska są nowe, dotyczą bowiem zjawisk negatywnych - takich jak np. deklasacja, tj. ruchliwość społeczna skierowana „w dół” - które pojawiły się po długim okresie pomyślności: wzrostu gospodarczego, niskiej stopy bezrobocia, powszechnej poprawy standardu życia.

- Po trzecie, istnieje dość powszechna zgoda, by wiązać ekskluzję społeczna z zasadniczymi przemianami gospodarczymi, które w ciagu ostatnich dwóch, trzech dekad pojawiły się na szczeblu regionalnym, narodowym i międzynarodowym, oraz z intensyfikacją konkurencji. Przemiany te obejmuje się ostatnio pojęciem globalizacji.

Według Kronauera do najważniejszych wymiarów ekskluzji należą wykluczenia:

${ }^{8}$ T. Kocowski, Potrzeby człowieka. Koncepcja systemowa, Warszawa-Wrocław 1982, s. 15. Por. T. Kazimierczak, M. Łuczyńska, Wprowadzenie do pomocy społecznej, Katowice 1998, s. 24.

${ }^{9}$ T. Kazimierczak, Praca socjalna. Między upośledzeniem społecznym a obywatelskościa, Katowice 2006 , s. 70. 
- z rynku pracy - długoterminowe bezrobocie bez szans na nową pracę;

- ekonomiczne - ubóstwo pojmowane w relacji do społecznej i kulturowej wartości standardów życia;

- kulturowe - dominujące wzory wartości i zachowań mają wyłączający efekt wobec tych, którzy są przywiązani do innych wzorów i je praktykują;

- przez izolację - kontakty i stosunki społeczne oraz tożsamość grupowa wyłącznie w obrębie zmarginalizowanych i naznaczonych;

- przestrzenne - specyficzne obszary miasta lub regionu zajęte przez wykluczonych;

- instytucjonalne - odwrót od inkluzyjnych warunków dostępu do instytucji opiekuńczych i bezpośrednie wykluczanie z dostępu do usług publicznych, takich jak szkoły ${ }^{10}$.

W tym kontekście dotykamy wieloznaczności pojęcia „ekskluzja”. Z jednej strony odnosi się ona do wielu różnych aspektów życia w społeczeństwie: ekonomicznych, politycznych, społecznych, kulturowych. Z drugiej strony o jej wieloznaczności świadczy fakt, że jednostka i rodzina mogą doświadczać wielu wykluczeń. Dlatego przy identyfikacji procesów ekskluzji należałoby zwrócić uwagę na dwie ważne kwestie, mianowicie, z czego jest się wykluczonym i kto wyklucza. Naszkicowany obraz omawianego terminu pozwala wskazać w jego obrębie trzy grupy. Pierwsza odnosi się do źródeł, przyczyn wykluczenia, druga określa jego wieloznaczność, a trzecia pokazuje jego formy.

Omówienie różnych typów podejścia do tematu biedy warunkuje stwierdzenie, że pojęcie ekskluzji może być określane w odniesieniu do biedy, która z kolei pośrednio określa granice wykluczenia społecznego, każdy ubogi bowiem jest wykluczony, ale nie każdy wykluczony musi być biedny. Rozumowanie powyższe ukazuje, jak trudno jest racjonalnie przejść od ekskluzji do wykluczenia społecznego. Zachowanie tych pojęć pozwala jednak wyodrębnić pewną dynamikę wewnętrznych procesów biedy (deprywacji). Natomiast wykluczenie, któremu poniekąd towarzyszy bieda, jest głębszym stopniem tej deprywacji. Dlatego można skonstatować, że wykluczenie jako pojęcie szersze znaczeniowo $\mathrm{w}$ teorii i praktyce obejmuje pewne aspekty procesualne i relacyjne biedy. Podobnie zresztą deprywacja jest równie stopniowalna jak inne zjawiska w społeczeństwie. Można być mniej lub bardziej wyłączonym z życia społecznego, można też być mniej bądź bardziej ubogim. Nie wchodząc zatem w dalsze meandry racjonalizacji ekskluzji, a zarazem unikając swoistego eklektyzmu, zwróćmy uwagę na samo pojęcie „wykluczenie społeczne”.

\footnotetext{
${ }^{10}$ T. Kazimierczak, Praca socjalna, s. 71.
} 
Na początku operacjonalizacji pojęcia „wykluczenie społeczne” należałoby jednak przyjąć kilka roboczych założeń definicyjnych, mianowicie:

- może być stanem i procesem; w obu przypadkach nie tylko obejmuje kwestię dystrybucji dóbr i mechanizmy ich alokacji, ale także inne procesy społeczne: stosunki władzy, stosunki kulturowe, stosunki ekonomiczne i in.;

- może być obiektywne i subiektywne (poczucie wykluczenia);

- może odnosić się do sytuacji jednostki i obejmować zarówno deficyt zasobów, jak i niemożność efektywnego uczestniczenia w życiu społecznym;

- może być traktowane jako pewna właściwość społeczeństwa, w którym istnieją wzory stosunków społecznych odgradzających dostęp jednostkom i grupom do zasobów i efektywnego uczestnictwa w życiu społecznym ${ }^{11}$.

Samo pojęcie wykluczenia społecznego ewaluowało długo i do dzisiaj nie ma jednoznacznej zgodności co do znaczeń definicyjnych omawianego zjawiska. Wydaje się zatem, że termin ten określa sytuację, w której dana jednostka będąca członkiem społeczeństwa nie może normalnie uczestniczyć w działaniach obywateli tego społeczeństwa, przy czym ograniczenie to nie wynika z jej wewnętrznych przekonań, ale znajduje się poza kontrolą wykluczonej jednostki. Wykluczenie społeczne jest zjawiskiem wielowymiarowym i w praktyce oznacza niemożność uczestnictwa zarówno w życiu gospodarczym, politycznym, jak i kulturowym, w wyniku braku dostępu do zasobów, dóbr i instytucji, ograniczenia praw społecznych oraz deprywacji potrzeb.

Według A. Giddensa ${ }^{12}$ wykluczenie społeczne (social exclusion) to efekt różnego rodzaju upośledzeń społecznych, wskutek których jednostka lub grupa nie może w pełni uczestniczyć w życiu gospodarczym, społecznym, ekonomicznym i politycznym społeczeństwa, do którego należy. Terminem tym dość często zastępowano pojęcie podklasy, chociaż wykluczenie społeczne jest określeniem szerszym oraz akcentuje formę procesu mechanizmów wykluczenia. Zdaniem socjologów, określa ono również pewien typ nierówności społecznej. Aby jednostka mogła dobrze funkcjonować w społeczeństwie, nie wystarczy jej tylko konsumpcja, ubranie i mieszkanie. Ważnym elementem jest dostęp do różnego typu usług i dóbr, czyli postaw solidarności społecznej, uaktywnionej przez różne instytucje.

${ }^{11}$ T. Kazimierczak, Praca socjalna, s. 51.

${ }^{12}$ A. Giddens, Socjologia, Warszawa 2006, s. 738. 


\section{PODMIOT WYKLUCZENIA SPOŁECZNEGO}

Podmiotem wykluczenia społecznego jest przede wszystkim jednostka, która na drodze realizacji własnego humanitas została wykluczona w sposób przez siebie zawiniony lub doznała wykluczenia z powodu słabej polityki państwa.

Grupami najbardziej narażonymi na wykluczenie społeczne są:

- osoby niepełnosprawne,

- osoby chore psychicznie,

- uzależnieni,

- długotrwale bezrobotni,

- opuszczający zakłady karne i poprawcze,

- kobiety samotnie wychowujące dzieci,

- ofiary patologii życia rodzinnego,

- osoby o niskich kwalifikacjach zawodowych,

- starsze osoby samotne,

- bezdomni,

- dzieci i młodzież ze środowisk zaniedbanych oraz wychowujące się poza rodziną,

- osoby będące imigrantami oraz członkowie mniejszości narodowych (np. członkowie społeczności romskiej).

Prawdopodobieństwo dotknięcia wykluczeniem zwiększa się, gdy jednostka ma kilka cech charakterystycznych dla wyżej wymienionych grup społecznych (np. uzależniony, długotrwale bezrobotny, chronicznie chory, imigrant). W tym kontekście dokonamy analizy niektórych zjawisk wykluczenia społecznego. Do tych najważniejszych wynikających z pewnych trudnych sytuacji społecznych można zaliczyć:

- niepełnosprawność,

- bezrobocie,

- bezdomność,

- uzależnienia,

- samotność i ubóstwo.

\section{A. Niepełnosprawni}

Do kategorii ludzi specjalnej troski należałoby zaliczyć niepełnosprawnych, którzy w sposób permanentny nie są w stanie podjąć żadnej pracy. Coraz częściej osoby te w społeczeństwie są dyskryminowane. Nawet infrastruktura spo- 
łeczna w wielu miejscach jest niedostosowana do warunków ich życia. Współczesny człowiek zapomina o nich, minimalizując ich egzystencję do małego procentu, traktując dość marginalnie. Tymczasem niepełnosprawni są pełnoprawnymi obywatelami życia społecznego. Należy się im praca w zakładach chronionych i normalne warunki życia. Nie mogą być traktowani jak osoby drugiej kategorii.

Niepełnosprawność jest jednym z bardzo ważnych zjawisk i problemów współczesności. Niestety, pierwszą trudność przy analizie tego zjawiska zauważa się już podczas próby jej zdefiniowania ${ }^{13}$. Aby zrozumieć, czym jest niepełnosprawność, należałoby się uprzednio odwołać do terminów „sprawność i pełnosprawność”.

Sprawność człowieka można rozpatrywać na kilku poziomach jego funkcjonowania. Trzy z nich wydają się tu szczególnie ważne. Można więc mówić o sprawności organizmu, traktując ją jako zdolność całego organizmu lub poszczególnych jego układów, względnie narządów (ruchowego, oddechowego, nerwowego, wzroku, serca itd.) do wypełniania właściwych im funkcji. Można także mówić o sprawności psychologicznej człowieka, traktując ją jako zdolność do samodzielnego (podmiotowego) organizowania własnego działania, które umożliwia mu zaspokojenie posiadanych potrzeb i wywiązywanie się z podstawowych zadań narzucanych przez otoczenie społeczne. Wreszcie można mówić o sprawności społecznej grupy, do której należy dana jednostka. Będziemy z nią mieli do czynienia, jeśli jej członkowie będą zdolni do podejmowania działań zespołowych, które zapewnią osiaganie odpowiednich celów grupowych, przypisywanych tej grupie przez otoczenie lub stawianych sobie spontanicznie przez uczestników grupy ${ }^{14}$.

Pełnosprawność może oznaczać dwa stany, w jakich będzie znajdował się człowiek. Z jednej strony będzie to pełna sprawność człowieka rozpatrywana na wszystkich trzech poziomach jego funkcjonowania: biologicznym, psychologicznym i społecznym. Z drugiej strony może chodzić o wypełnianie wszystkich funkcji, zadań i celów w poszczególnych etapach egzystencji człowieka. Podobnie w dwojaki sposób można traktować niepełnosprawność, jako naruszenie sprawności na jednym z wyróżnionych poziomów albo jako częściową utratę zdolności funkcjonowania $\mathrm{w}$ ramach jednego $\mathrm{z}$ poziomów ${ }^{15}$.

Gdy mówimy o osobach niepełnosprawnych, mamy na uwadze przede wszystkim ludzi, których organizmy są dysfunkcjonalne (utraciły zdolność

${ }^{13} \mathrm{~W}$ języku polskim dość często używa się zamiennie innych określeń, takich jak: inwalidztwo, kalectwo, upośledzenie, defekt fizyczny lub psychiczny itd. Por. G. Chojnacka-Szawłowska, K. Szawłowski, Rehabilitacja, Warszawa 1994; K.J. Zabłocki, Psychologiczne i społeczne wyznaczniki rehabilitacji zawodowej inwalidów, Warszawa 1995.

${ }^{14}$ S. Kowalik, Psychospołeczne podstawy rehabilitacji osób niepetnosprawnych, Katowice 1999, s. 24

${ }^{15}$ Tamże, s. 25. 
do wypełniania właściwych im funkcji). Biologiczne uszkodzenie ciała może dodatkowo utrudniać człowiekowi sprawne funkcjonowanie na dwóch pozostałych poziomach, ale nie jest konieczne do rozpoznania niepełnosprawności, którą będę też zamiennie nazywał dysfunkcjonalnością organizmu. Starając się zachować pewną precyzję, proponuję nazywać dysfunkcjonalnością utraconą sprawność organizmu, jego układów lub narządów. Natomiast niepełnosprawność oznaczałaby coś więcej, a mianowicie utratę zdolności do funkcjonowania nie tylko na poziomie biologicznym, ale również na poziomach psychologicznym i społecznym. Obejmowałaby ona swoim zakresem pierwotny defekt biologiczny organizmu (dysfunkcjonalność), a także jego skutki psychologiczne i społeczne ${ }^{16}$.

Kontakt z tymi osobami nastręcza wielu ludziom szczególnych problemów interakcyjnych. Główną przyczynę tego faktu należy upatrywać w tym, że jako społeczeństwo nie umiemy jeszcze właściwie traktować osób sprawnych inaczej ani kontaktować się z nimi. Wynika to z braku wiedzy o sytuacji socjalnej tych osób i bardzo często w takich sytuacjach subiektywnie pojawiającego się zakłopotania, litości, żalu, altruizmu, nadopiekuńczości lub też uprzedzeń, lekceważenia bądź pogardy wobec tzw. „innych” osób.

Osoby niepełnosprawne stanowią $10 \%$ populacji w wieku produkcyjnym. Jednakże ich udział w łącznym zatrudnieniu wynosi zaledwie $3,8 \%{ }^{17}$. Tak niski udział osób niepełnosprawnych w zatrudnieniu może wynikać z:

- większych niż przeciętne trudności w znalezieniu pracy,

- mniejszej chęci czy też możliwości wejścia na rynek pracy.

Ogólnie rzecz biorąc, stopa bezrobocia i wskaźnik aktywności zawodowej osób niepełnosprawnych na rynku pracy mogą posłużyć do określenia sposobu oddziaływania tych dwóch czynników. Coraz częściej pracodawcy nie chcą zatrudniać niepełnosprawnych, uważają bowiem, że osoby te są mniej wydajne i mogą stwarzać wiele komplikacji.

Wykluczenie osób niepełnosprawnych w sferze społecznej dotyczy nie tylko kwestii zatrudnienia. Zauważa się je w ogóle w ogólnodostępnych środkach życia społecznego: w jego strukturze i polityce społecznej. Jak dotąd nadal w wielu miejscach naszego kraju infrastruktura nie jest dostosowana do ich potrzeb. Problemy te zauważa się w niewystarczającym dostosowaniu środków transportu do ich życia, dotyczy to również możliwości załatwienia spraw w różnych instytucjach, także pomoc społeczna względem tych osób często jest zwykłą iluzją. Jedynie w sporcie niepełnosprawni mogą się realizować, ale czynią to wyłącznie

16 Tamże.

17. P. Czapliński, Raport o stanie zatrudnienia osób niepetnosprawnych w Polsce, Warszawa 2010. 
ci, którzy do końca walczą o swój status w społeczeństwie, bo nigdy nie będzie to droga dla wszystkich.

Wykluczenie niepełnosprawnych wynika nie tylko z zaniedbań ze strony państwa. Wywołuje je także ogólna świadomość statystycznego Polaka. Współcześnie ludzie unikają niepełnosprawnych, jakby byli oni osobami gorszej kategorii. Tymczasem osoby te domagają się uznania właściwej im godności. Nie liczą na użalanie się nad nimi, ale chcą być pełnoprawnymi obywatelami w społeczeństwie.

\section{B. Bezrobotni}

Kolejna grupa społecznego wykluczenia to bezrobotni, których można nazwać „skazanymi na rynku pracy”. Bezrobocie ${ }^{18}$ od dawna jest przedmiotem zainteresowania socjologów i psychologów, ponieważ ze względu na swoje następstwa stanowi doniosły problem społeczny. Podczas gdy ekonomiści analizuja jego przyczyny i rozważają metody ograniczenia tego zjawiska, socjologowie i psychologowie skupiają uwagę na jego konsekwencjach. Badania skutków bezrobocia nabierają intensywności w okresach szczególnego nasilenia tego zjawiska. Tak było w latach 30 . XX wieku w okresie Wielkiego Kryzysu i tak stało się w latach 70. i 80. ubiegłego stulecia, gdy w większości krajów należących obecnie do Unii Europejskiej poziom bezrobocia ogromnie wzrósł i stało się ono znów zjawiskiem masowym. Przyczyniły się do tego nie tylko recesja ekonomiczna, lecz także wprowadzenie nowych technologii oszczędzających pracę ludzką, niedostosowanie kwalifikacji osób poszukujących pracy do tych technologii, restrukturyzacja przemysłu, zmiany w organizacji pracy, a także konkurencja tanich towarów z krajów Trzeciego Świata.

Współcześnie bezrobocie należy do bardzo ważnych problemów w społeczeństwie. Coraz więcej jest osób, które nie mogą znaleźć pracy w miejscu swojego zamieszkania bądź niedaleko od niego. Wydaje się więc, że ludzie ci są wykluczeni, brak pracy bowiem czyni z nich osoby biedne, ubogie, nieradzące sobie z problemami indywidualnie ani kolektywnie. Wszak z powodu bezrobo-

${ }^{18}$ Warto przypomnieć definicję bezrobocia zaczerpniętą z Ustawy o promocji zatrudnienia; „Art. 2 ust 1 pkt. 2: Bezrobotnym jest osoba niezatrudniona i niewykonująca innej pracy zarobkowej, zdolna i gotowa do podjęcia zatrudnienia w pełnym wymiarze czasu pracy obowiązującym w danym zawodzie lub służbie albo innej pracy zarobkowej (a jeżeli jest osobą niepełnosprawną: zdolna i gotowa do podjęcia zatrudnienia co najmniej w połowie tego wymiaru czasu pracy), nieucząca się w szkole (z wyjątkiem szkoły dla dorosłych lub osoby przystępującej do egzaminu eksternistycznego z zakresu tej szkoły lub ucząca się w szkole wyższej w systemie wieczorowym, zaocznym lub eksternistycznym) zarejestrowana we właściwym dla miejsca zameldowania stałego lub czasowego powiatowym urzędzie pracy oraz poszukująca zatrudnienia lub innej pracy zarobkowej”. Por. Ustawa o promocji zatrudnienia z 20 kwietnia 2004 Art. 2 ust 1. pkt. 2. 
cia cierpi także cała rodzina. Skala bezrobocia od wielu lat utrzymuje się na względnie wysokim poziomie, chociaż były lata, w których zjawisko to istotnie malało. Należy do nich zaliczyć okres przystapienia Polski do struktur Unii Europejskiej. Na przestrzeni ostatnich 20 lat skala bezrobocia przedstawia się następująco.

Tabela 1

Zjawisko eskalacji bezrobocia w Polsce w ostatnim dwudziestoleciu

\begin{tabular}{|c|c|c|c|}
\hline Rok & $\begin{array}{c}\text { Liczba bezrobotnych } \\
\text { zarejestrowanych } \\
\text { (w tysiącach) }\end{array}$ & $\begin{array}{c}\text { Stopa bezrobocia } \\
\text { wedlug UP }\end{array}$ & $\begin{array}{c}\text { Stopa bezrobocia } \\
\text { wedlug BAEL }\end{array}$ \\
\hline 1990 & 1126,1 & 6,5 & - \\
\hline 1991 & 2155,6 & 12,2 & 13,7 \\
\hline 1992 & 2509,3 & 14,3 & 14,9 \\
\hline 1993 & 2890,6 & 16,4 & 13,9 \\
\hline 1994 & 2838,0 & 16,0 & 13,1 \\
\hline 1995 & 2628,8 & 14,9 & 11,5 \\
\hline 1996 & 2359,5 & 13,2 & 10,2 \\
\hline 1997 & 1826,4 & 10,3 & 10,6 \\
\hline 1998 & 1831,4 & 10,4 & 15,3 \\
\hline 1999 & 2349,8 & 13,1 & 16,0 \\
\hline 2000 & 2702,6 & 15,1 & 18,5 \\
\hline 2001 & 3115,1 & 17,5 & 19,7 \\
\hline 2002 & 3217,0 & 18,0 & 19,3 \\
\hline 2003 & 3175,7 & 20,0 & 18,0 \\
\hline 2004 & 2999,6 & 19,1 & 16,7 \\
\hline 2005 & 2773,0 & 17,6 & 13,0 \\
\hline 2006 & 2309,4 & 14,9 & 9,6 \\
\hline 2007 & 1746,6 & 11,2 & 7,1 \\
\hline 2008 & 1473,8 & 9,5 & 10,0 \\
\hline 2009 & 1583,4 & 11,7 & 19 \\
\hline 2010 & 1883,3 & & \\
\hline 2011 & W pierwszym i drugim kwartale ogólna stopa bezrobocia wyniosła 1,9 & 19 \\
\hline
\end{tabular}

Źródło: GUS, Rocznik statystyczny 1992; 1995; 2005; GUS, Aktywność ekonomiczna ludności Polski w latach 1992-2004, Warszawa 2005; GUS, Mały rocznik statystyczny Polski, 2009, Mały rocznik statystyczny, 2010.

${ }^{19}$ Wiadomości telewizyjne program $1 \mathrm{z}$ dnia 16.08.2011. 
Wykres 1

Zjawisko eskalacji bezrobocia w Polsce w ostatnim dwudziestoleciu według stopy bezrobocia UP i BABEL (dane w \%)

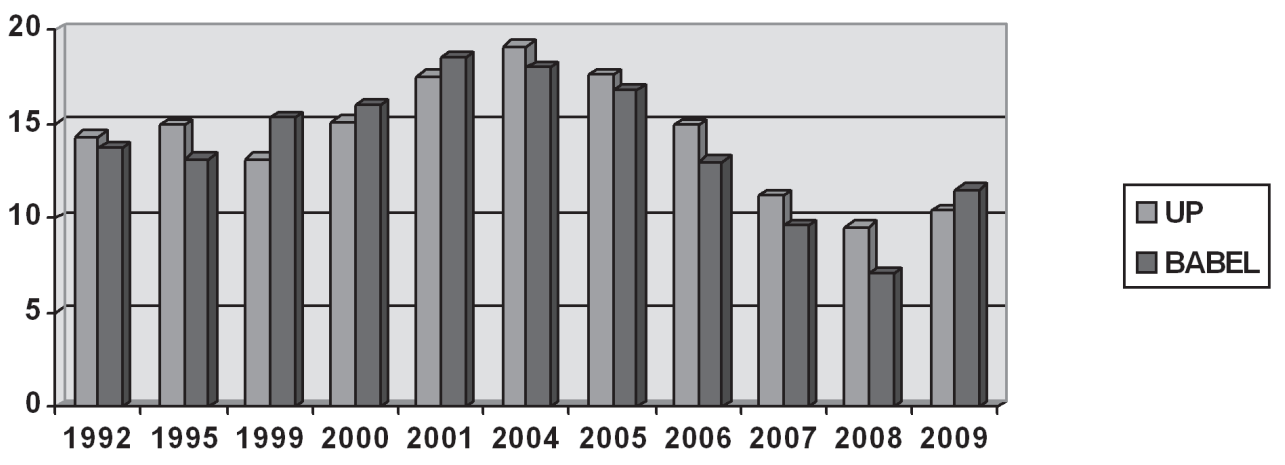

Źródło: Opracowanie własne na podstawie danych: GUS, Rocznik statystyczny 1992; 1995; 2005; GUS, Aktywność ekonomiczna ludności Polski w latach 1992-2004, Warszawa 2005; GUS, Maty rocznik statystyczny Polski, 2009, Mały rocznik statystyczny, 2010.

Konsekwencjami bezrobocia (zwłaszcza długotrwałego ${ }^{20}$ ), jak stwierdza M. Szylko-Skoczny, dla większości bezrobotnych są: pogorszenie standardu życia, a nawet ubóstwo, problemy z zagospodarowaniem czasu wolnego, izolacja społeczna, poczucie obniżenia statusu, ograniczenie lub zaniechanie uczestnictwa w życiu politycznym, kulturalnym i w życiu społeczności lokalnej. Towarzyszy temu dyskomfort psychiczny, polegający często na poczuciu bezsilności, a czasami nawet beznadziejności ${ }^{21}$.

Pogłębiające się bezrobocie, przy tym niedostatek rodziny, izolacja społeczna, jak również niemożność znalezienia nowej pracy, wreszcie zależność od innych osób, przeżywanie upokorzeń i obniżenie statusu prowadzi do pogorszenia samopoczucia. Zwiększa się bowiem niepokój o przyszłość, poczucie bezradności, a może nawet pojawić się brak szacunku do siebie. Dłuższy czas bezrobocia prowadzi do tego, że bezrobotny zaczyna nienawidzić siebie, swojego życia.

Bezrobocie rozpatrywane w skali makrostrukturalnej niesie ze sobą groźbę wykluczenia społecznego. Jako proces wielowymiarowy wykluczenie oznacza brak lub ograniczenie możliwości uczestnictwa w działalności podstawowych instytucji publicznych, wpływania na nie i korzystania z nich. To również uniemożliwienie bądź znaczne utrudnienie odgrywania ról społecznych, korzystania

\footnotetext{
${ }^{20}$ Więcej o długotrwałym bezrobociu warto przeczytać: G. Gęsicka, Dlugoterminowe bezrobocie, ,Rynek Pracy” 11-12(1992), s. 9-36.

${ }^{21}$ Por. M. Szylko-Skoczny, Bezrobocie jako kwestia społeczna, Warszawa 1987.
} 
z dóbr publicznych, gromadzenia dochodów. Oznacza też załamanie stosunków społecznych. Bezrobotni jako kategoria społeczna są szczególnie narażeni na wykluczenie społeczne i doświadczają wielu jego przejawów. Dzieje się tak głównie ze względu na niekorzystne warunki ekonomiczne. Ubóstwo bowiem stanowi zarówno przyczynę, jak i przejaw wykluczenia. Bezrobotni są również narażeni na wykluczenie społeczne z powodu niedostosowania do zmieniających się warunków społecznych i ekonomicznych. Polega ono w głównej mierze na braku odpowiednich, z punktu widzenia rynku pracy, kwalifikacji czy cech społecznodemograficznych. Jednak wykluczenie jako zjawisko wielowymiarowe nie jest tylko rezultatem cech, którymi wyróżniają się jednostki. Ma ono również źródła w otoczeniu zewnętrznym. Jest rezultatem uprzedzeń, braku właściwego ustawodawstwa, braku odpowiednich instytucji bądź wadliwego ich funkcjonowania. Wykluczenie przejawia się rezygnacją z korzystania ze wszystkich dostępnych społecznie możliwości takich, jak: praca, konsumpcja, relacje społeczne. Obejmuje również sferę polityki. Badania dowodzą, że bezrobotni nie głosują i nie angażują się w działalność społecznąa22.

Aby zrozumieć dramat bezrobocia, należy uświadomić sobie znaczenie pracy dla jednostki, rodziny i społeczeństwa. Jak zapisał Jan Paweł II -

Praca stanowi podstawę kształtowania życia rodzinnego, które jest naturalnym prawem i powołaniem człowieka. Te dwa kręgi wartości - jeden związany z pracą, drugi wynikający z rodzinnego charakteru życia ludzkiego - muszą łączyć się z sobą prawidłowo i prawidłowo wzajemnie przenikać. Praca jest poniekąd warunkiem zakładania rodziny, rodzina bowiem domaga się środków utrzymania, które w drodze zwyczajnej nabywa człowiek przez pracę (LE 10).

Praca determinuje cały układ życia człowieka, jego styl życia, relacje społeczne. Tymczasem coraz więcej osób jest jej pozbawionych. Wśród nich są również młodzi ludzie, którzy po ukończeniu szkoły nie znajdują zatrudnienia. Coraz więcej pracodawców zwraca uwagę na doświadczenie, dlatego też więcej jest bezrobotnych młodych ludzi niż starszych, ale i tych ostatnich dotyka brak pracy. O ile bezrobocie trwa krótki czas, do $1 \frac{1}{2}$ roku, może nie mieć poważnych konsekwencji, jeśli zaś jest długotrwałe, wówczas ludzie popadają w przygnębienie i pustkę egzystencjalną, zaś starsi ulegają różnym niekorzystnym dla życia zjawiskom społecznym, nawet alkoholizmowi.

${ }^{22}$ Zob. M. Szylko-Skoczny, Bezrobocie, s. 63; tenże, Diagnoza społeczna, Warszawa 2005. Por. Warunki i jakość życia Polaków, red. J. Czapiński, T. Panek, Warszawa 2005, s. 278; L. Frąckiewicz, Wykluczenie społeczne w skali mikro i makroregionalnej, w: Wykluczenie społeczne, red. L. Frąckiewicz Katowice 2005, s. 11-26; S. Golimowska, Od ubóstwa do wykluczenia społecznego, „Polityka Społeczna” 11-12 (2006), s. 1. 


\section{Bezdomni}

Bezdomni to kolejna grupa osób wykluczonych w systemie społecznym. Podobnie jak bezrobocie i bieda, bezdomność jest zjawiskiem ciagle obecnym w życiu społecznym. Zjawisko to można analizować jako rodzaj sytuacji egzystencjalnej konkretnej jednostki, która doświadcza jej z różnych przyczyn. $Z$ jednej strony mogą być one zawinione przez nią, z drugiej od niej niezależne. Bezdomność to nie tylko brak domu i możliwości mieszkania w nim, to przede wszystkim poważny problem psychospołeczny mający wpływ na pojawienie się i rozwój innych, jak np.: alkoholizmu, niezdolności do samodzielnego rozwiązywania problemów, przestępczości. Współcześnie liczba osób bezdomnych rośnie. Niektórzy znaleźli się w tej sytuacji z powodu własnej nieporadności, braku chęci do pracy, inni zaś to ofiary złego systemu społecznego lub choroby, która uniemożliwiła im właściwe funkcjonowanie.

Najczęściej przez bezdomność rozumie się stan ludzkiej egzystencji przejawiający się w permanentnym braku stałego zamieszkania. Istnieje wiele definicji bezdomności. Zdaniem E. Moczuk, to względnie trwała sytuacja człowieka nieposiadającego własnego mieszkania albo w ogóle pozbawionego dachu nad głową ${ }^{23}$. P. Poławski uważa, że zjawisko bezdomności to proces społeczny, w który zaangażowane są różne osoby i grupy osób, przede wszystkim te, które mają z bezdomnymi bezpośredni kontakt $\mathrm{z}$ racji wykonywania zawodu, niosą im pomoc, decydują o zasadach dystrybucji środków ${ }^{24}$. Według A. Duracz-Walczak bezdomnym jest człowiek niemający miejsca spełniającego warunki mieszkalne, w którym mógłby stale przebywać, ani aktualnej możliwości lub chęci uzyskania takiego miejsca ${ }^{25}$.

B. Smykowska ${ }^{26}$ uważa, że bezdomnych można podzielić na dwie grupy:

- pierwsza grupa, to ludzie zdegenerowani, podatni na patologie, którym można pomóc jedynie doraźnie, np. skierować ich do schroniska, wyrobić im dowody osobiste, dać odzież czy udzielić pomocy medycznej;

- druga grupa, zwana współczesnymi bezdomnymi, to żyjący w skrajnej i długotrwałej nędzy, którzy nawet mając mieszkanie, mogą je łatwo stracić.

W literaturze przedmiotu wyróżnia się kilka rodzajów bezdomności. Do najważniejszych należy zaliczyć bezdomność:

${ }^{23}$ E. Moczuk, Bezdomność jako problem społeczny w świadomości osób bezdomnych, „Polityka Społeczna” 10 (2000), s. 43.

${ }^{24}$ P. Poławski, Obrazy bezdomnych i bezdomności. Instytucjonalizacja reakcji na problem spoteczny, „Polityka Społeczna” 1(2001), s. 15.

${ }_{25}$ A. Duracz-Walczak, Bezdomność w Polsce. O ujednolicenie pojęć, „Polityka Społeczna” 5-6 (1998), s. 28.

${ }^{26}$ D. Smykowska, Instytucje wsparcia społecznego, Łódź 2007, s. 241. 
- całkowita,

- częściową,

- czasową,

- zawiniona,

- niezawiniona.

Prawdopodobnie do chwili obecnej nie powstało żadne opracowanie tematyczne poświęcone wprost osobom bezdomnym, nieposiadającym miejsca zamieszkania czy też zagrożonym wykluczeniem mieszkaniowym. Cytowane dane i definicje pochodzą z raportu pt. Mieszkania 2002 z sierpnia 2003 roku oraz Ludność. Stan i struktura demograficzno-społeczna z lipca 2003 roku.

- Zarejestrowano 771 obiektów zbiorowego zakwaterowania dla bezdomnych, w których spisano 13997 osób zaliczonych do grona stałych mieszkańców. W raportach nie ma dokładnej definicji „obiektu zbiorowego zakwaterowania przeznaczonego dla bezdomnych" ani też sposobu zaliczania osoby do grona stałych mieszkańców. W niektórych tabelach jako obiekty wymienione są same schroniska lub schroniska i noclegownie. Niemożliwe jest przypisanie otrzymanych liczb do jednej bądź kilku kategorii definicji operacyjnej bezdomności i wykluczenia mieszkaniowego. Prawdopodobnie jednak za obiekty zbiorowego zakwaterowania dla bezdomnych uznano placówki z kategorii 2 i 3, czyli noclegownie i schroniska o różnym okresie pobytu.

- Zarejestrowano 112 „domów pomocy społecznej dla samotnych kobiet w ciąży lub z małymi dziećmi”, w których spisano 2271 osób zaliczonych do grona stałych mieszkańców.

- Spisano 5700 zamieszkanych pomieszczeń niebędących mieszkaniami oraz 11500 mieszkających w nich osób.

- Ogólna liczba osób niemających miejsca zamieszkania nie jest podana we wspomnianym raporcie, istnieje natomiast możliwość ich uzyskania poprzez złożenie zamówienia w GUS. W liczbie tej zawarte są zarówno osoby mieszkające w miejscach zbiorowego zakwaterowania dla bezdomnych, jak i osoby przybywające w miejscach niemieszkalnych oraz inne.

- Liczba osób mieszkających w mieszkaniach o warunkach substandardowych została ustalona na 6481200.

- Liczba osób, na które przypada $7 \mathrm{~m}^{2}$ i mniej powierzchni użytkowej, została ustalona na 225 828. Grupę tę można uznać za mieszkającą w warunkach przeludnienia ${ }^{27}$.

${ }^{27}$ http://www.pfwb.org.pl/wp-content/uploads/2010/01/feantsa-statystyczna-dla-pomost-2005. pdf $\mathrm{z}$ dnia 18.08.2011. 
Badania wskazuja, że bezdomność jest najczęściej domeną samotnych mężczyzn, którzy z różnych powodów nie radzą sobie ze swoim życiem. Statystycznie polski bezdomny pozostaje bez dachu nad głową przez około 6 lat. Pierwszą przyczyną takiego położenia jest alkohol, inną nieporozumienia w rodzinie. Zwykle jednak przyczyn bezdomności jest o wiele więcej. Bezdomność, jako zjawisko społeczne dotykające według różnych danych od kilkunastu do nawet kilkuset tysięcy ludzi w Polsce, jest bez wątpienia poważną kwestią społeczną. Stanowi przykład patologii społecznej i marginalizacji.

Zjawisko bezdomności, będące przejawem wykluczenia społecznego, bez wątpienia lokuje się w grupie problemów społecznych, dotyka bowiem ogółu społeczeństwa. Zakłóca jego prawidłowe funkcjonowanie i niesie różnorodne formy zagrożenia. Czasem jest to problem nie do rozwiązania. Od kilkunastu lat stanowi jednak poważną kwestię społeczną. Jest zjawiskiem, którego skali nie da się dokładnie oszacować, chociaż można wskazać, ilu ludzi korzysta z pomocy dla bezdomnych ${ }^{28}$. Jest to jednak, jak się wydaje, zjawisko wielowymiarowe, niejednolite i niejednorodne.

\section{Uzależnieni}

Jeszcze inną grupą lokującą się wśród wykluczonych społecznie są osoby uzależnione od alkoholu, narkotyków i innych środków odurzających. Uzależnienie jest stanem, w którym jednostka odczuwa nieodpartą potrzebę zażycia toksycznej substancji, co wiąże się z jej wcześniejszym nadużywaniem. Ponadto uzależnienie od produktu oznacza konieczność jego regularnego konsumowania, by uniknąć skutków odstawienia, które objawia się różnymi problemami fizycznymi i psychicznymi.

$\mathrm{Z}$ terminem uzależnienia łączy się pojęcie nawyku. Jest to pokrewny termin, który oznacza zautomatyzowany, szablonowy składnik działalności, formujący się w procesie wielokrotnego powtarzania i ćwiczenia jakiejś czynności. Nawyki są elementami składowymi złożonych umiejętności i celowej działalności, automatyzacji ulega nie tylko sam sposób wykonania; w szerokim ujęciu nawykiem mogą być również celowo czy przypadkowo ustalone sprawności motoryczne i umysłowe, a także postawy uczuciowe, przekonania, metody pracy ${ }^{29}$.

${ }^{28}$ Brak dokładniejszych informacji o skali zjawiska bezdomności w Polsce. Liczbę osób bezdomnych określa się od 30 do nawet 300 tysięcy. Jedynym miarodajnym źródłem wiedzy w tym zakresie jest liczba osób, którym formalnie udzielona została pomoc przez ośrodki pomocy społecznej. Liczba ta ulega okresowym zmianom, oscylując wokół wartości 30 tysięcy. W 2002 roku liczba ta wyniosła 31382 osoby. Natomiast ze sprawozdań nadsyłanych przez organizacje pozarządowe do Ministerstwa Pracy i Polityki Społecznej, w związku z udzieloną dotacją na pomoc osobom bezdomnym wynika, że udzielają one pomocy ok. 80-130 tys. osobom. Szacunkowe dane określające liczbę bezdomnych na 300 tysięcy pochodzą od Stowarzyszenia Monar.

${ }_{29}$ J. Młyński, Człowiek wobec pomocy... Zarys pracy socjalnej, Tarnów 2009, s. 169. 
W życiu społecznym najczęściej obserwuje się uzależnienia, do których należy zaliczyć: alkoholizm i narkomanię. Obydwa są niepokojącymi zjawiskami współczesnego świata. Nie tylko niszczą człowieka, ale mają olbrzymie konsekwencje dla życia rodzinnego.

Powszechnie wiadomo, że od zarania dziejów alkohol towarzyszył człowiekowi oraz społeczeństwu i odciskał piętno na rodzinach. Alkoholizm to stan, w którym dany człowiek sięga po alkohol, mimo iż powoduje to dokuczliwe skutki dla niego i otoczenia. Jest to choroba tak głęboko zaburzająca świadomość i wolność człowieka, że dla zdecydowanej większości uzależnionych okazuje się śmiertelna. W 1956 roku alkoholizm został wpisany na listę chorób Światowej Organizacji Zdrowia (WHO). Jest to jedna z najbardziej destrukcyjnych chorób i jednocześnie jedna $z$ niewielu, w których chory twierdzi, że jest zdrowy.

Nadużywanie alkoholu jest zjawiskiem powszechnym i związanym z naszą tradycją. Znaczna część społeczeństwa akceptuje taki stan „rzeczy”, a abstynencję traktuje jako przejaw dziwactwa ${ }^{30}$. Nadużywający alkoholu wywodzą się z różnych sfer. Stanowią oni ok. 15\% ogółu społeczeństwa. Nadużywanie alkoholu jest przyczyną braku spójności w rodzinie, braku organizacji, powoduje również straty w gospodarce.

Niestety, zjawisko to odciska swoje piętno nie tylko na uzależnionej jednostce, ale przede wszystkim na rodzinie, dzieciach i współmałżonku. Prowadzi do zmiany wartości i więzi, a także do zmniejszenia wolności i odpowiedzialności osoby uzależnionej. Zwykle dopiero na końcu pojawiają się skutki fizyczne, zdrowotne. Skoro pod wpływem alkoholu zostaje zaburzona podstawowa zdolność człowieka do wypełniania niektórych funkcji, oczywiste jest to, że ma to ogromne znaczenie dla funkcjonowania tej osoby w społeczeństwie i w rodzinie. W zależności od tego, kto nadużywa alkoholu, zmienia się struktura rodziny. Oczywiście dla dzieci najgorszą sytuacją jest, gdy oboje rodziców dotyka problem alkoholowy. Niektórzy nawet określają dzieci alkoholików jako osoby z problemem alkoholowym. Istnieje również pojęcie DDA, czyli „dorosłe dzieci alkoholików”, które będąc przez wiele lat pod wpływem rodziny z problemem alkoholowym, same w przyszłości mogą powielić tę formę egzystencji.

Rodziny, w których nadużywa się alkoholu, charakteryzują się nie tylko dewiacyjnością odgrywania ról małżeńskich i rodzicielskich, ale także dezorganizacją środowiska rodzinnego, rozkładem jej wewnętrznej struktury, tzn. występuje zaburzony układ stosunków wewnątrzrodzinnych. Dezorganizacja spowodowana jest rozpadem stosunków między małżonkami oraz między rodzicami i dziećmi, a nawet między dziećmi. Relacje rodzica nadużywającego alkohol z pozostałymi członkami rodziny są zazwyczaj nacechowane brutalnością, agresywnością, pozbawio-

\footnotetext{
${ }^{30}$ B. Woronowicz, Alkoholizm jest chorobq, Warszawa 1990, s. 8.
} 
ne są podłoża emocjonalnego, charakteryzują się także obojętnością, brakiem zainteresowania, bezuczuciowością. Czasami pojawia się brak stabilności więzi, co przejawia się raz zachowaniem serdecznie wylewnym, innym razem zachowaniami wrogimi, agresywnymi. Obok takich negatywnych układów pojawiają się układy harmonijne (dziecko i rodzic, który nie nadużywa alkoholu). Takie rodziny nie zaspokajają nawet podstawowych potrzeb każdego swojego członka. Nie są też zdolne wywiązać się z zadań, jakie stawia przed nimi społeczeństwo ${ }^{31}$.

Niedostatek materialny, mieszkaniowy, częste konflikty, a także wystapienie zjawisk patologicznych, np. niepohamowanego popędu seksualnego alkoholika, prostytucji matek alkoholiczek, nielegalnego handlu alkoholem, kradzieży, bójek, związków kazirodczych, samobójstw, zabójstw, powodują społeczny i psychiczny rozkład rodziny, wywołują też u jej członków stan niezaspokojenia potrzeb biologicznych i psychicznych, w szczególności zaś potrzeb bezpieczeństwa i kontaktu emocjonalnego. Taka sytuacja ma nieuchronny wpływ na proces uspołecznienia dziecka, które uwikłane w tak negatywne, wręcz agresywne stosunki, przyswaja sobie wadliwe wzory ról społecznych, uczy się również agresywnych zachowań, które przenoszone są na kontakty pozarodzinne. Dzieci, których potrzeby są niezaspokojone z powodu braku opieki, szukają zaspokojenia poza rodziną, czyniąc to często w sposób nieakceptowany. Z powodu choroby alkoholowej jednego z rodziców szkoda wyrządzona rodzinie jest bardzo rozległa i dotyka głównie dzieci. Dziecko jest zależne od rodziców, co zmniejsza jego szanse na ucieczkę z tego otoczenia, które staje się jego własnym miejscem. Dziecko alkoholika jest w dużym stopniu narażone na powtórzenie losów uzależnionych rodziców ${ }^{32}$. Ponadto w rodzinie z problemem alkoholowym nie jest zaspokajana potrzeba kontaktu międzyludzkiego, panuje natomiast wszechobecna samotność, izolacja oraz wyobcowanie rodzinne i społeczne.

Wreszcie oczywistym wymiarem destrukcji alkoholika jest jego degradacja moralna. Tracąc kontrolę nad nałogiem, wszystko jemu podporządkowuje. Dlatego tak wiele krzywd w rodzinie, płaczu, a także zagrożeń fizyczno-psychicznych. Wydaje się zatem, że alkoholizm w rodzinie to jedna $\mathrm{z}$ pierwszych form jej dezintegracji. $Z$ powodu tego uzależnienia w Polsce rozpada się prawie co czwarta rodzina. Gdyby doliczyć do nich te, które zachowują małżeństwo z powodów religijnych, rozpadów tych byłoby o wiele więcej.

Najbardziej niepokojącym zjawiskiem zauważalnym wśród młodych ludzi jest narkomania. Według rejestrów policyjnych w 1996 roku w Polsce było 2212 nieletnich narkomanów. Liczby te jednak nie oddają w pełni faktycznej skali zjawiska. Według danych szacunkowych co trzeci uczeń szkoły średniej miał kontakt ze środkami odurzającymi. Wielu narkomanów weszło na drogę przestępczą

${ }^{31}$ E. Drążek, A. Drążek, Uwagi na temat alkoholizmu, czyli trucizna w akcji, w: Patologie naszych czasów, red. A. Drążek, E. Drążek, Białystok 2007, s. 186.

32 Tamże, s. 187. 
zazwyczaj pod wpływem środków odurzających. Częściej jednak przestępstwa odbywały się pod wpływem alkoholu. Przestępstwa te to najczęściej napaści, pobicia, w tym i te najbardziej brutalne. O skali przestępstw świadczy liczba osób zatrzymywanych w izbach wytrzeźwień.

Narkomania nie jest w Polsce zjawiskiem nowym. Występowała już przed I wojną światową i w okresie międzywojennym. Powszechnym problemem społecznym stała się w naszym kraju na przełomie lat 60. i 70., gdy z Zachodu przeniknęły do Polski wpływy kontestacji młodzieżowej i kontrkultury hippisowskiej, chętnie podejmowane przez młodych Polaków jako forma protestu nie tylko przeciwko dorosłym, ale i przeciw istniejącej wówczas napiętej sytuacji politycznej oraz społecznej. Narkomania rozpowszechniła się wówczas w środowiskach młodzieżowych, tworzonych dotąd przez dzieci z „dobrych domów”33.

Narkomania jako uzależnienie prowadzące do wykluczenia społecznego objęła w Polsce chyba wszystkie kategorie wiekowe społeczeństwa. Dotyczy zarówno starszych, młodych, jak i całych rodzin. Najwięcej jednak narkomanów znajduje się wśród młodzieży, która na różny sposób stała się ofiarą tego zjawiska. Narkomania to jednak zjawisko bardzo złożone, uwarunkowane wieloma czynnikami, między innymi: filozoficznymi, religijnymi, psychologicznymi, wychowawczymi, społecznymi, a nawet ekonomicznymi. Narkomani przejawiają aspołeczne zachowania, do których należy zaliczyć:

- szybkie wypadanie ze swoich ról społecznych,

- wykazywanie nieprzystosowania społecznego (drażliwości, zmienności nastroju),

- nieuznawanie przez nich miłości, przyjaźni, lojalności,

- popełnianie przestępstw (wyrób narkotyków i handel nimi, kradzieże itp.),

- nakłanianie innych do przyjmowania narkotyków,

- kradzieże, włamania do szpitali, aptek,

- fałszowanie, wyłudzanie recept, rozboje, znieważenie, gwałty, samobójstwa, bezczynność i obojętność, bierność,

- jedna osoba może przyczynić się w krótkim czasie do zarażenia dziesięciu innych.

Nie ma możliwości pełnej oceny zasięgu zjawiska narkomanii na podstawie oficjalnych danych statystycznych resortów oświaty, zdrowia oraz spraw wewnętrznych, lecz dotychczas stanowią one główne źródło informacji o narkomanii w naszym kraju. Są one jednak niemiarodajne i nie mogą w pełni oddać ist-

${ }^{33}$ A. Drążek, E. Drążek, Co warto wiedzieć o narkotykach i terapiach przeciwdziałajacych temu uzależnieniu, w: Patologie naszych czasów, s. 84. 
niejącej sytuacji epidemiologicznej, zawierają informacje zarówno o osobach uzależnionych, wymagających leczenia i podejmujących takie leczenie, jak i o osobach nieuzależnionych, przyjmujących narkotyki incydentalnie oraz o takich, które same nie zażywając środków odurzających, weszły w związku z nimi w kolizję z prawem ${ }^{34}$.

Narkomania występująca wśród młodzieży pogłębia formy jej niedostosowania społecznego. Młodzież, która sięga po środki odurzające, uwikłana jest w konflikty osobiste i społeczne. Zdarzają się wśród narkomanów osoby z zaburzeniami rozwoju psychicznego. Ucieczka w ,świat iluzji” ma rozwiązać ich problemy. Narkotyki powodują zaś jeszcze większe konflikty z otoczeniem, porzucenie nauki czy pracy, wkroczenie na drogę przestępczą. $\mathrm{Z}$ roku na rok wzrasta liczba narkomanów znajdujących się w rejestrach policyjnych, którzy nie uczą się i nie pracują.

Narkomania staje się współcześnie bardzo niepokojącym społecznie zjawiskiem. Chociaż nie znamy jej skali, to jednak wiemy, że dotyczy dużej części społeczeństwa. Nie ulega wątpliwości, że osoby uzależnione znajdują się niejako poza nawiasem społeczeństwa. Budowane są dla nich specjalne ośrodki, a statystyczny Polak jest wobec narkomanów bierny, bo ma świadomość, że problem ten jest zawiniony, i rzeczywiście w dużej mierze tak jest. Nikt bowiem nie zmusza młodych ludzi do brania narkotyków.

\section{E. Samotni i ubodzy}

Analiza problematyki ubóstwa i samotności jako zjawisk wykluczenia społecznego jest bardzo trudna. Trudności te konkretyzują się w terminologii: kto jest osobą samotną, kto jest osobą ubogą. Zasadniczym problemem jest ustalenie kryteriów, które zobrazują samotność i ubóstwo. Przyznać należy, że wszelkie definicje słownikowe i encyklopedyczne cechują się dużym stopniem ogólności. Niektórzy autorzy stwierdzaja, że ubóstwo to pewien sposób niedoboru, inni twierdza, iż jest to brak wystarczających środków materialnych do właściwej egzystencji. Jeśliby przyjać powyższe definicje za właściwe, to należałoby się zastanowić na zaspokajaniem podstawowych potrzeb ludzkich.

W literaturze spotyka się dwa rozróżnienia pojęcia biedy i ubóstwa. Ubóstwo absolutne i relatywne. Ubóstwo absolutne odnosi się do możliwości uzyskania przez jednostkę zasobów potrzebnych do zaspokojenia jej egzystencji pozwalającej osiagnąć jedynie minimum środków na przetrwanie. Ubóstwo w tym wymiarze dotyczy jedynie tych, którzy pozostają poniżej owego minimum. Określenie to wskazuje jedynie na przetrwanie jednostek w danym społeczeństwie. Ubóstwo relatywne dotyczy zaś tych jednostek, które znajdują się w sytuacji

${ }^{34}$ D. Smykowska, Instytucje, s. 257. 
możności przetrwania, których dochody są znacząco mniejsze od reszty jednostek żyjących w tym samym społeczeństwie. Standard ich życia jest wprawdzie poniżej przeciętnego poziomu, ale nie stanowi ich tylko minimum dochodów ${ }^{35}$.

Niezależnie od przyjętych powyżej definicji biedy absolutnej i relatywnej może warto byłoby zwrócić uwagę na ubóstwo subiektywne, czyli to, które bezpośrednio dotyczy danej jednostki. Jednostka ta może nie mieścić się w podziale relatywnym i absolutnym, ale subiektywnie czuje się osobą biedną i wykluczoną. Tak czy inaczej w świadomości społecznej bieda wiąże się szczególnie z niedostatkiem w budżetach domowych.

Niedostatek materialny to $\mathrm{z}$ jednej strony ograniczenia finansowe, $\mathrm{z}$ drugiej zawężenie możliwości w różnych sferach życia jednostki i rodziny. Mówi się o wykluczeniu materialnym, na które składają się różne przyczyny, których można szukać w wielu dziedzinach życia społecznego. Geneza wykluczenia materialnego sięga czasem daleko w przeszłość i składa się na nią wiele czynników jednocześnie. Gdy jest to stan głęboki i wielowymiarowy, mówi się o syndromie biedy $^{36}$. Ludzie wykluczeni to ci, którzy nie korzystają, ponieważ nie mogą korzystać, niezależnie od swojej woli, z formalnie przypisanych im praw i przywilejów społecznych ${ }^{37}$.

Osoby biedne, żyjące poniżej linii ubóstwa ${ }^{38}$, powinny stać się osobnym przedmiotem zainteresowania sytemu społecznego. Ich niedostatek godzi nie tylko we właściwą egzystencję, ale w godność człowieka, albowiem człowiek, który permanentnie nie zaspokaja swoich podstawowych potrzeb, czuje się poniżony, a jego godność osobista wydaje się zagrożona ${ }^{39}$. W ten sposób ulega procesom marginalizacji i wykluczenia społecznego. W tym kontekście warto się przypatrzeć skali omawianego zjawiska.

Zdaniem A. Ochockiego, „,dokonywane szacunki przy zastosowaniu różnych linii ubóstwa dochodowego jednoznacznie wykazały, że zjawisko to nasiliło się w Polsce szczególnie w 1990 roku. Było to konsekwencją upadku gospodarki tzw. realnego socjalizmu. Wówczas dochody wszystkich grup ludności uległy silnemu obniżeniu. Najsłabsze grupy znalazły się w strefie zagrożenia ubóstwem,

\footnotetext{
${ }^{35}$ Por. J. Młyński, Deprywacja społeczna a pracy socjalna. Komplementarność zjawisk czy znaczna różnica, „Praca Socjalna” 4(2008), s. 4-14.

${ }^{36}$ Zrozumieć biednego. O dawnej i obecnej biedzie w Polsce, red. E. Tarkowska, Warszawa 2000.

${ }^{37}$ E. Wnuk-Lipiński, Socjologia życia publicznego, Warszawa 2005.

${ }^{38}$ Więcej na ten temat warto przeczytać: A. Ochocki, Demograficzne i przestrzenne aspekty ubóstwa, w: Przeciw ubóstwu i bezrobociu: lokalne inicjatywy obywatelskie, red. J. Hrynkiewicz, Warszawa 2002; T. Panek, Ubóstwo: od definicji do pomiaru, w: Polityka społeczna globalna i lokalna, red. A. Kurzynowski, Warszawa 2000; J. Auleytner, Polityka społeczna, czyli ujarzmianie chaosu socjalnego, Warszawa 2002.

${ }^{39}$ Por. L. Dyczewski, Teoretyczna i praktyczna rola Kościoła katolickiego w walce z ubóstwem, Polska bieda. Kryteria. Ocena. Przeciwdziałanie, Warszawa 1996, s. 18.
} 
a część z tych rodzin, zwłaszcza rodziny bezrobotnych i rodziny wielodzietne, stały się po pewnym czasie trwale ubogimi" ${ }^{40}$.

W 1990 roku liczba ludności osiaggającej niskie dochody podwoiła się, a odsetek osób żyjących w rodzinach poniżej minimum socjalnego przekroczył $30 \%$. Według szacunków Instytutu Pracy i Spraw Socjalnych odsetek ten przekroczył 40\% w 1994 roku. Według danych GUS, w 2000 roku ponad 50\% ludności utrzymywało się w gospodarstwach domowych, w których poziom wydatków był niższy od minimum socjalnego. W raporcie Banku Światowego oszacowano, że w latach osiemdziesiątych odsetek ludności ubogiej wynosił w Polsce od 5\% do 10\%, a w 1990 roku odsetek ten podniósł się do $15 \%$. W opracowaniu tym za lin i ę ubóstwa w każdym roku analizowanego okresu przyjęto siłę nabywczą minimalnej emerytury z 1993 roku (World Bank, 1995) ${ }^{41}$.

\section{Ponadto}

prześledzenie zmian wskaźnika ludności ubogiej w dłuższym okresie jest możliwe na podstawie oszacowań GUS przy zastosowaniu relatywnej i subiektywnej linii ubóstwa. I tak, odsetek osób żyjących w gospodarstwach domowych, których wydatki nie przekraczały połowy średnich wydatków ekwiwalentnych wynosił 12\% w 1993 roku, podniósł się do $17,1 \%$ w 2000 roku. Wyraźny i systematyczny wzrost tego wskaźnika postępował od 1996 roku (14,0\%). W 1993 roku aż 40\% gospodarstw domowych sytuowało się poniżej subiektywnej 1 i n i i ubóstwa. W kolejnych dwóch latach 1994 i 1995 odsetek ten obniżył się do poziomu około 30\% i utrzymywał się na tym poziomie do 1998 roku, aby ponownie wzrosnąc do ponad 34\% w 2000 roku. Widać więc wyraźnie, że w okresie ożywienia gospodarczego (1994-1997) i spadku stopy bezrobocia (1994-1998) postrzeganie biedy było mniejsze ${ }^{42}$.

W 2000 roku, jak stwierdza A. Ochocki,

stosując różne 1 in i e ubóstwa, uzyskano następujące oszacowania frakcji osób ubogich (GUS, 2001):

- $8,1 \%$ poniżej minimum egzystencji,

- $13,6 \%$ poniżej ustawowej granicy ubóstwa,

- $17,1 \%$ poniżej relatywnej granicy ubóstwa.

Jest to sytuacja lokująca Polskę pod względem zasięgu ubóstwa za takimi krajami, jak: Czechy, Słowacja, Węgry i Słowenia (UNDP, 2001) ${ }^{43}$.

Według danych GUS dla IV kwartału 20054: ok. 12\% społeczeństwa znajdowało się w skrajnej biedzie, czyli poniżej minimum egzystencji; dla jednooso-

${ }^{40}$ A. Ochocki, Zagrożenie trwatym ubóstwem rodzin i gospodarstw domowych $w$ Polsce, w: Rodzina Polska u progu trzeciego tysiaclecia, red. W. Majkowski, Warszawa 2003, s. 35.

${ }^{41}$ Tamże, s. 35.

${ }^{42}$ Tamże, s. 35-36.

${ }^{43}$ Tamże, s. 36.

${ }^{44}$ Warunki życia ludności w 2004, 2005 r., GUS, Warszawa 2006. 
bowego gospodarstwa domowego wynosiło ono wówczas 387 zl, dla czteroosobowej rodziny - rodziców z dwojgiem dzieci - 1045 zł; ok. 18\% (20\% w 2004) żyło w warunkach umiarkowanego ubóstwa, czyli tzw. ubóstwa relatywnego, określanego na poziomie 50\% średnich miesięcznych dochodów gospodarstw domowych; wynosiło ono wówczas odpowiednio 479 i 1292 zł; ok. 1\% (19\% w 2004) wynosił zasięg tzw. ubóstwa ustawowego, określanego na poziomie dochodów uprawniających do pomocy społecznej; było to odpowiednio 461 i $1264 \mathrm{zł;}$ ok. 23\% (spadek z 27,3\% w roku 2004) wynosiła stopa ubóstwa tzw. subiektywnego, czyli wyznaczonego opinią badanych, że im „ledwie wystarcza”; kształtowało się ono na poziomie $941 \mathrm{zł}$ dla jednoosobowego gospodarstwa, $1492 \mathrm{zl}$ dla czteroosobowego. Według szacunków ok. 10\% ludności Polski żyje w warunkach biedy przedłużającej się lub utrwalonej. Tak więc można podsumować, że biegun skrajnego ubóstwa wynosi w Polsce około 10-12\% ludności, natomiast w warunkach biedy umiarkowanej, uprawniającej do korzystania z pomocy społecznej żyje około $18 \%$, czyli niemal $1 / 5$ społeczeństwa.

W 2007 roku na zlecenie Komisji Europejskiej we wszystkich krajach Unii zostało przeprowadzone specjalne badanie ankietowe dotyczące postrzegania przez opinię publiczną zjawiska ubóstwa i społecznego wykluczenia. Objęto nim około 26,5 tys. osób w wieku 15 lat i więcej (po ok. 1000 osób w każdym z krajów, z wyjątkiem Cypru i Malty, gdzie próba liczyła po ok. 500 osób). Z badania tego wynika m.in., że przeciętny mieszkaniec Unii Europejskiej uważa, że w miejscu jego zamieszkania (w najbliższej okolicy) - 39\% osób doświadcza sytuacji, które wskazują na to, że żyją one w ubóstwie (w tym co 10 osoba w skrajnym ubóstwie). Jako żyjący w biedzie postrzegani są przede wszystkim mieszkańcy „nowych krajów członkowskich” (w 12 nowych krajach członkowskich jako doświadczających sytuacji ubóstwa, w tym skrajnego, postrzeganych jest $63 \%$ osób, a 32\% osób w krajach „starej piętnastki”). Przeciętny Polak sądzi, że w okolicy, w której mieszka, ubóstwem dotkniętych jest $64 \%$ osób, w tym skrajnym ubóstwem - 20\%. Cytowane dane świadczą o tym, jak bardzo rozpowszechnione jest $\mathrm{w}$ świadomości społecznej poczucie zagrożenia biedą i jak duża jest skala tego problemu w Europie (pomimo że w pewnym stopniu opinie respondentów wynikają jedynie z przypuszczeń, subiektywnych ocen, a nie ze znajomości faktycznych warunków życia osób postrzeganych jako ubogie $)^{45}$.

Zjawisko biedy ciagle się rozszerza. $Z$ danych Eurostatu przeprowadzonych w 2008 roku wynika, że co szósty obywatel Unii Europejskiej żyje w skrajnej biedzie. W Polsce parametr ten wynosi $17 \%{ }^{46}$. W istocie trudno jest oszacować zjawi-

${ }^{45}$ A. Szukiełojć-Bieńkuńska, Ubóstwo w Polsce na tle krajów Unii Europejskiej-podstawowe fakty $i$ dane, w: http://eapn.org.pl/ [dostęp 19.08.2011].

${ }^{46}$ Materiaty z konferencji prasowej z dn. 28 stycznia 2010, GUS, Departament Warunków $\dot{Z}$ ycia. 
sko biedy w naszym kraju. Niezależnie od przyjętych parametrów biedy w poszczególnych latach niezaprzeczalne jest to, że coraz więcej osób żyje w biedzie. Może nie jest to jeszcze bieda skrajna, ale należy zauważyć, że w obserwowanym świecie skrajnej biedy również nie brakuje. Zasięg ubóstwa materialnego jest bardzo duży, dlatego należy skupić się nad tymi, którzy nie mogą zaspokoić nawet swoich podstawowych potrzeb, związanych z właściwym funkcjonowaniem w społeczeństwie.

Czynnikiem decydującym o statusie ekonomicznym, w tym o sytuacji materialnej jednostek i rodzin, jest miejsce zajmowane przez członków rodzin na rynku pracy. W największym stopniu wykluczeniem materialnym zagrożone są osoby i rodziny osób, które mają problemy ze znalezieniem i utrzymaniem pracy. Jak podaje GUS, w 2005 roku wśród gospodarstw domowych, w skład których wchodziła przynajmniej jedna osoba bezrobotna, stopa ubóstwa skrajnego wynosiła ok. $27 \%$ (9\% w rodzinach bez osób bezrobotnych $)^{47}$.

Wykluczenie materialne najbardziej zagraża - co oczywiste - rodzinom, w których problemy ze znalezieniem pracy trwają od wielu miesięcy lub lat. Dlatego na szczególną uwagę zasługuje bezrobocie długotrwałe, czyli pozostawanie bez pracy powyżej 12 miesięcy. Jest to stała cecha polskiego bezrobocia i trzeba podkreślić, że w ostatnim okresie, kiedy nastapiła zdecydowana poprawa na rynku pracy ${ }^{7}$, długotrwałe bezrobocie jest ciagle bardzo wysokie ${ }^{48}$.

Permanentne skrajne ubóstwo dotyka przede wszystkim osoby samotne i starszych. Emeryci w ostatniej dekadzie jesieni życia nie są w stanie się utrzymać. Brakuje im pieniędzy na żywność, na lekarstwa, dlatego też niektórzy z nich zmuszeni są do żebractwa. Jeżeli statystyczny polski emeryt otrzymuje ok. 800 zł emerytury, to za te środki nie da się nawet egzystować, a co dopiero myśleć o przeciętnym życiu. Właśnie osoby starsze w szczególny sposób zostały poddane procesom marginalizacji i wykluczenia społecznego, chore i niedołężne szukają pomocy. Ale gdzie mają ją znaleźć? Jaka instytucja dostrzeże szarość ich życia i będzie w stanie udzielić pomocy?

\section{JAK POMAGAĆ JEDNOSTKOM SKAZANYM NA WYKLUCZENIE SPOŁECZNE}

Pomoc społeczna dotyczy różnych aspektów egzystencji jednostki. Z jednej strony integralnie zajmuje się człowiekiem jako podstawową jednostką społeczną, z drugiej traktuje go jako jednostkę znajdującą się w grupach społecznych.

\footnotetext{
${ }^{47}$ Zasięg ubóstwa materialnego w 2005 r. w: GUS, Warszawa 2007.

${ }^{48}$ Stopa bezrobocia w latach 1990-2007, w: GUS, http://www.stat.gov.p]/gus/45_677_PLK HTML.htm; zob. też J.K. Kowalski, Bezrobocie może wynosić tylko 7\%, „The Wall Streeet Journal Polska", 26 czerwca 2007; M. Danecka, Sytuacja na rynku pracy, w: Ocena postępów Polski w zakresie spójności z Unia Europejska, Raport CASE, Warszawa 2007.
} 
Pomoc społeczna jest instytucją polityki społecznej państwa, mającą na celu umożliwienie osobom i rodzinom przezwyciężanie trudnych sytuacji życiowych, których nie są one w stanie pokonać, wykorzystując własne uprawnienia, zasoby i możliwości. Organizuje ją administracja rządowa i samorządowa, współpracując w tym zakresie, na zasadzie partnerstwa, z organizacjami społecznymi i pozarządowymi, Kościołem katolickim, innymi Kościołami, związkami wyznaniowymi oraz osobami fizycznymi i prawnymi. Jej zadaniem jest wspieranie osób i rodzin w wysiłkach zmierzających do zaspokojenia niezbędnych potrzeb oraz umożliwienie im życia w warunkach odpowiadających godności człowieka. Ponadto do zadań pomocy społecznej należy zapobieganie trudnym sytuacjom przez podejmowanie działań zmierzających do życiowego usamodzielnienia osób i rodzin, a także ich integracji ze środowiskiem. Praca socjalna to jedno z głównych zadań gminy w zakresie pomocy społecznej ${ }^{49}$.

Pomoc społeczna, jako instytucja polityki społecznej państwa, ingeruje wtedy, gdy osoba lub rodzina nie są w stanie własnymi siłami przezwyciężyć trudnych sytuacji życiowych. Organizują ją organy administracji rządowej i samorządowej. Współpracują w tym zakresie z organizacjami społecznymi, Kościołami, fundacjami i stowarzyszeniami, pracodawcami oraz osobami fizycznymi i prawnymi.

Zakłada się, że pomoc społeczna powinna w miarę możliwości doprowadzać do życiowego uaktywnienia osoby korzystającej ze świadczeń, a także jej integracji ze środowiskiem społecznym. Adresowana jest do obywateli polskich i cudzoziemców mających prawo stałego pobytu lub status uchodźcy, mieszkających i przebywających na terytorium Rzeczypospolitej Polskiej. Osoby i rodziny, które korzystają z pomocy społecznej, są zobowiązane do współudziału w rozwiązywaniu swoich trudnych sytuacji życiowych przy wsparciu ze strony pracownika socjalnego ${ }^{50}$.

W tym kontekście warto przytoczyć cele pomocy społecznej. Zalicza się do nich:

- wsparcie osób i rodzin w przezwyciężeniu trudnej sytuacji życiowej, doprowadzenie - w miarę możliwości - do ich życiowego usamodzielniania i umożliwienie im życia w warunkach odpowiadających godności człowie$\mathrm{ka}$;

- zapewnienie dochodu na poziomie interwencji socjalnej - dla osób nieposiadających dochodu lub o niskich dochodach, w wieku poprodukcyjnym i osobom niepełnosprawnym;

- zapewnienie dochodu do wysokości poziomu interwencji socjalnej osobom i rodzinom o niskich dochodach, które wymagają okresowego wsparcia;

${ }^{49}$ Ustawa o pomocy społecznej z dn. 12 marca 2004 r., (Dz.U. M 64, późniejszymi zmianami 593 z dnia 15 kwietnia 2004 r.).

${ }^{50}$ Por. C. Sutton, Psychologia dla pracowników socjalnych, Gdańsk 2004, s. 241. 
- zapewnienie profesjonalnej pomocy rodzinom dotkniętym skutkami patologii społecznej, w tym przemocą w rodzinie;

- integracja ze środowiskiem osób wykluczonych społecznie;

- stworzenie sieci usług socjalnych adekwatnych do potrzeb w tym zakresie ${ }^{51}$.

Państwo w swoim podmiocie polityki społecznej obejmuje:

- ośrodki pomocy społecznej na terenie gmin, udzielające pomocy pieniężnej, usługowej i rzeczowej oraz kierujące do domów pomocy społecznej;

- powiatowe centra pomocy rodzinie; prowadzą one domy pomocy społecznej, zapewniają opiekę nad dziećmi w placówkach opiekuńczo-wychowawczych, np. domy dziecka, pogotowia opiekuńcze, rodziny zastępcze;

- regionalne ośrodki polityki społecznej (należą do nich urzędy marszałkowskie, które zajmują się koordynacją polityki społecznej na określonym terytorium):

- województwa, wydziały polityki społecznej, kontrola gmin i powiatów.

Pierwszym podstawowym zadaniem polityki socjalnej jest pomaganie osobom znajdującym się na marginesie życia społecznego. Chodzi przede wszystkim o tych, którzy w sposób niezawiniony uczestniczą w wielu procesach wykluczenia społecznego. Wśród wielu działań wspomagających osoby wykluczone warto zwrócić uwagę na pomoc bezdomnym. Główne jej formy i sposoby przeciwdziałania bezdomności to:

- Działania o charakterze profilaktycznym zapobiegające utrwalaniu się i poszerzaniu zjawiska bezdomności. W praktyce oznacza to konieczność wyodrębnienia tych jednostek i grup społecznych, których sytuacja społeczno-ekonomiczna wymaga podjęcia wobec nich działań o charakterze profilaktycznym, odpowiedniej selekcji przypadków osób zagrożonych bezdomnością. Profilaktyka powinna być kierowana do osób i grup społecznych, wychowanków opuszczających dom dziecka, osób opuszczających zakłady karne bez możliwości zamieszkania, osób wywodzących się ze środowisk patologicznych, skrajnego ubóstwa.

- Działania o charakterze osłonowym - zapobiegające degradacji społecznej każdej kategorii osób bezdomnych z zastosowaniem standardowych form i rodzajów świadczeń pomocy, winny być kierowane przede wszystkim do osób rokujących wyjście z bezdomności.

- Działania o charakterze aktywizującym - zmierzające do wyprowadzenia z bezdomności konkretnych osób i grup społecznych, na

${ }^{51}$ Por. R. Gierszewska, Pomoc społeczna, w: Leksykon polityki społecznej, Warszawa 2002. 
przykład tworzenie w każdej gminie co najmniej trzech miejsc pobytu dla ludzi bezdomnych, wspieranie placówek świadczących usługi na ich rzecz $^{52}$.

Należy wspomnieć o pomocy względem osób uzależnionych, zagrożonych ubóstwem. Z pewnością nie jest łatwo walczyć $\mathrm{z}$ alkoholizmem czy narkomanią, ale jest to zadanie instytucji wsparcia społecznego, zwłaszcza opartych na profilaktyce. Istnieje bardzo dużo ośrodków pomocowych dla tej grupy ludzi. Ośrodki te mają charakter państwowy i kościelny. Należy przyznać, że Kościół jako instytucja charytatywna bardzo mocno angażuje się w różnych obszarach pomocy tym ludziom.

Przezwyciężanie problemu ubóstwa związane jest przede wszystkim z funkcjonowaniem systemu opieki społecznej. Opiera się on na działaniu takich placówek, jak: gminne ośrodki opieki społecznej, powiatowe centra pomocy rodzinie oraz centra pomocy społecznej. Zajmują się one między innymi oceną problemu ubóstwa, bezdomności, patologii społecznych na swoim terenie. $\mathrm{Na}$ rzecz takich ludzi działa również wiele innych organizacji, np. MONAR ${ }^{53}$. Ciekawą inicjatywą jest prowadzenie centrum medycznego, świadczącego pomoc lekarska.

Problem ubóstwa w naszym kraju nie jest zbadany na tyle, by podać dokładne dane. Nieoficjalne źródła mówią natomiast, że może to dotyczyć nawet 28$-30 \%$ społeczeństwa. Bezrobocie, ubóstwo, bezdomność są ze sobą powiązane. Jeżeli ktoś przez dłuższy czas pozbawiony jest pracy, poziom jego życia znacznie się obniża. Bezrobocie jest wynikiem gospodarki tzw. wolnorynkowej, jeśli przekracza 5\%, jest znacznym problemem dla państwa.

Opracowywano również wiele programów zwalczania bezrobocia. Program aktywny to jedna z opcji zwalczania bezrobocia, zaliczają się do niego m.in. roboty publiczne, pożyczki na tworzenie małych przedsiębiorstw. Najskuteczniejsze są jednak programy szkolące tych, którzy nie mogą znaleźć pracy w swoim zawodzie. Najmniej skuteczne są programy pasywne (zasiłki dla bezrobotnych, świadczenia przedemerytalne, wcześniejsze emerytury finansowane przez ZUS). Młodzi ludzi zaczynają rozumieć powyższy problem, dlatego coraz większy procent decyduje się na dalszą edukację. Dzięki temu Polska pod tym względem jest krajem bardzo dobrze rozwiniętym.

Najpewniejszym sposobem rozwiązania problemu bezrobocia jest aktywizacja wzrostu gospodarczego. Wymaga to sporych zmian w polityce kraju. Podatki, tanie kredyty, ulgi inwestycyjne to tylko niektóre modyfikacje, jakie należy wprowadzić, aby skutecznie zwalczyć zjawisko bezrobocia.

${ }^{52}$ D. Smykowska, Instytucj, s. 242.

${ }^{53}$ Z. Bauman, Praca, konsumpcjonizm i nowi ubodzy, Kraków 2006, s. 20-22. 
W pomocy społecznej powinny znaleźć się programy wspierające ludzi biednych, wykazujących długookresowe trudności w zdobywaniu pracy, rodziny w bardzo trudnych sytuacjach życiowych oraz osoby samotne, chore i bezradne. Jedną z charakterystycznych cech instytucji pomocy społecznej, umożliwiających jej pełnienie funkcji socjalnych w sposób społecznie efektywny, jest jej otwartość na współpracę z innymi, a szczególnie z organizacjami pozarządowymi i wyznaniowymi. Współdziałanie takie widać obecnie na poziomie lokalnym. Jednak nie rozwija się ono z taką samą dynamiką na wyższych szczeblach, szczególnie administracji centralnej, a przy tym pojawiają się ciagle liczne bariery i konflikty.

Reasumując, należy podkreślić, że pomoc społeczna w naszym kraju nieustannie się rozwija, jest to dość młoda dyscyplina, ale zawiera bardzo ważne aspekty życia ludzkiego. Może dotyczyć każdego, dlatego ważne jest, aby polityka w tym sektorze ciągle się udoskonalała. Tworzone są, nowelizowane i aktywowane ustawy dotyczące bezrobocia, biedy, niepełnosprawności. Państwo stara się ciagle merytorycznie walczyć z powyższymi zjawiskami. Inwestuje, aby ulepszać gałęzie gospodarki publicznej tak, aby każda osoba mogła z nich czerpać korzyści i znaleźć potrzebną pomoc. Jednym z najważniejszych praw obywateli jest prawo do godnego życia. Pod szczególną opieką państwa znajdują się rodziny, dzieci, osoby niepełnosprawne oraz osoby, które z różnych powodów nie są w stanie samodzielnie zabezpieczyć swoich podstawowych potrzeb życiowych, aby godnie żyć.

Obowiązkiem władz publicznych jest zapewnienie im pomocy. Zakres działań państwa $\mathrm{w}$ tym względzie reguluje obecnie Ustawa o pomocy społecznej z dnia 12 marca 2004 roku. Pomoc społeczna jest instrumentem polityki społecznej państwa, który umożliwia osobom samotnym i rodzinom przezwyciężanie problemów i trudności życiowych, których nie są one w stanie pokonać samodzielnie.

„Artykuł 71 Konstytucji Rzeczypospolitej mówi o tym, że państwo w swojej polityce społecznej i gospodarczej uwzględnia dobro rodziny. Obowiązkiem państwa wobec tego jest nie tylko udzielanie pomocy, ale przede wszystkim prowadzenie takich działań, które będą wzmacniały rodzinę. Działania te powinny być prowadzone poprzez walkę z bezrobociem, biedą i ubóstwem, poprzez wspieranie działalności organizacji charytatywnych, zajmujących się problemami osób niepełnosprawnych, przewlekle chorych, a także stowarzyszeń zakonnych, które również prowadzą działalność opiekuńczą. Szczególne znaczenie powinno mieć również poradnictwo i profilaktyka w zakresie najczęściej spotykanych problemów społecznych"54.

Realizacja polityki społecznej i gospodarczej uwzględniającej dobro rodzinny powodowałaby zmniejszenie bezrobocia, biedy i ubóstwa wśród społeczeń-

\footnotetext{
${ }^{54}$ Konstytucja RP. Artykut 71.
} 
stwa, a co za tym idzie, zmniejszałyby się potrzeby obywateli w zakresie pomocy społecznej, co z kolei skutkowałoby zmniejszaniem się wydatków państwa i likwidowaniem „dziury budżetowej”. W związku z powyższym głównym celem państwa powinno być przede wszystkim stwarzanie społeczeństwu takich warunków, które umożliwiałyby każdemu obywatelowi samodzielne zarobkowanie i utrzymywanie się...

\section{KOŃCOWE REKOMENDACJE}

Rzeczywistość współczesnego świata jest niezwykle złożona. Z jednej strony świat podlega procesom rozwoju, technicyzacji, globalizacji i pluralizmu; z drugiej zaś polityczne, gospodarcze i kulturowe losy społeczeństw uwarunkowane historycznie, geograficznie, a nawet klimatycznie, sprawiają, że współczesnemu człowiekowi przychodzi zmagać się z niespotykanymi dotąd trudnościami wynikającymi z jego egzystencji. Nader często uświadamiamy sobie, że „w globalnej wiosce" jest coraz więcej jednostek biednych i potrzebujących. W takiej konstrukcji rzeczywistości problemy ubóstwa, bezdomności, uzależnień i samotności jawią się jako podmiot pomocy społecznej.

Istnieje kilka kierunków polityki społecznej, które mogą służyć poprawie skuteczności rozwiązywania różnych problemów:

1. Zwiększenie roli państwa w rozwiązywaniu problemów społecznych w zakresie: ubóstwa, bezrobocia, bezdomności, samotności i niepełnosprawności. W żadnej mierze nie ogranicza to organizacji publicznych i ich działalności względem tych problemów. Należy jednak pamiętać, że administracja państwowa ma dodatnią sumę środków, które może wykorzystać do przeciwdziałania omawianym problemom i dlatego w jakimś stopniu ponosi odpowiedzialność za cały system pomocy społecznej.

2. Należy uwzględnić działalność charytatywną i dobroczynną, ale powinnością państwa jest odchodzenie od tego typu pomocy. System charytatywny sprawdza się jedynie w pewnym wymiarze, zaś pomoc państwa musi być dobrze zorganizowana.

3. Konieczna wydaje się standaryzacja środków pomocy wobec bezrobotnych, bezdomnych ubogich i niepełnosprawnych.

4. Jednym $z$ ważnych kryteriów lepszego zorganizowania pomocy jest diagnozowanie zjawiska. Współcześnie istnieje problem diagnozy zjawiska, jej brak zamyka działalność pomocową w kręgu błędnego koła, nigdy bowiem nie będzie wiadomo, komu należy pomagać.

5. Należałoby poprawić skuteczność programów zapobiegających społecznym problemom. 
6. Pomoc społeczna powinna zostać zobligowana do wnikliwego badania współczesnych problemów oraz skutecznie i sprawiedliwie rozdawać środki osobom potrzebującym

Pomoc społeczna jest jednym z elementów polityki społecznej państwa i tym samym stanowi fragment systemu zabezpieczenia społecznego. Wynika to z celów, jakie przed nią stoją: zaspokajania niezbędnych potrzeb życiowych osób i rodzin oraz umożliwienia im bytowania $\mathrm{w}$ warunkach odpowiadających godności człowieka, przy czym pomoc społeczna powinna w miarę możliwości doprowadzić do życiowego usamodzielnienia osób i rodzin oraz do ich integracji ze środowiskiem, a także zapobiegać powstawaniu trudnych sytuacji życiowych, których nie są w stanie same rozwiązać.

Konkludując, należy stwierdzić, że istnieją braki i niedostatki, błędy i zaniedbania w każdej dziedzinie polityki społecznej. Najsilniej dotykają one grupy i jednostki najsłabsze. Wskutek owych braków w polityce społecznej oraz w jej przedmiotowych zakresach: w polityce ludnościowej, rodzinnej, edukacyjnej, mieszkaniowej, polityce podziału dochodu, zabezpieczenia społecznego, zatrudnienia, następuje erozja najsłabszych ogniw systemu społecznego. Konieczne zatem wydaje się otwarcie polityki państwa na różne problemy społeczne, nie zawsze zawinione przez jednostkę, ale przez system, w którym się ona znalazła.

\section{ABSTRACT}

The society in which today's man exists is not only difficult but also complicated. That is why many people cannot cope with personal and social problems. Many of them experience social exclusion defined as the effect of various social disabilities, due to which an individual or a group cannot fully participate in social, economical and political life of the society to which they belong. The subject of social exclusion is most of all an individual, who was excluded on his way to realize his own humanitas due to his own faults or because of improper policy of the country. The most important problems located within the area of exclusion include: disability, unemployment, homelessness, addictions, loneliness and destitution.

The above mentioned areas of exclusion are characterized and the author attempts to indicate ways to help those who have become victims of exclusion. The basic institution which helps the excluded is social aid, whose first and foremost aim is improving social life. Within social aid, social workers play an important role, since as educated and competent they can have an influence on improving a person's life. Unfortunately, the basic needs of an excluded person are not always adequately addressed. These shortcomings affect most of all the weakest groups and individuals. Due to deficiencies in social policy and its subject areas: population, family, education, housing, income sharing, social security, employment - there occurs erosion of the weakest links of the social system. Thus there is a need of opening the policy of the state towards various social problems which are not always the fault of an individual but of the system, to which he/she belongs.

\section{Key words}

social exclusion, marginalization, poverty, homelessness, disability, loneliness, social aid, social worker, social policy 